V. Kozyr, Academician of the NAAS, Doctor of Agricultural Sciences

A. Maistrenko, G. Dymchia, Candidates of Agricultural Sciences Institute of grain crops of NAAS

\title{
FEEDING LEVEL OF REPAIR PIGLETS AND SUBSEQUENT PRODUCTIVITY OF SOWS IN CONDITIONS OF STEPPE ZONE
}

The purpose. To study productivity of standard and author's balancing feed additives at growing pigs.Methods. Groups-analogs (control and experimental), zootechnical, statistical, morphological, economic. Results. Expediency is proved of feeding repair piglets and sows with author's feed additives at their add-on to feed compounds twice less, than standard.

Conclusions. The recommended feed additives improve utilization of nutritive matters of a ration on synthesis of products due to rising its digesting. That favours to increase of daily average incremental values of repair piglets, decrease of expenditures of feedstuffs for $1 \mathrm{~kg}$ of mass increase and augmentation of productivity of sows.

Key words: repair piglets, sow, breed, feeding, feed additive, productivity.

One of the problems in pig breeding is the inadequacy of the feeding of repair guinea pigs and the subsequent low productivity of sows due to the imbalance of dietary nutrition, which negatively affects the efficiency of the industry. To prevent this scarcity, scientists from many research institutions offer feed additives for various soil and climatic regions of Ukraine. There are also those for the steppe zone. But most of the proposals do not take into account the actual chemical composition of the feed of the biogeochemical zone, age, live weight and physiological state of animals, and generally recommend the introduction of a ton of feed, which results in their low efficiency $[3,4]$. This indicates the need to find solutions to this problem. Therefore, research in this direction is relevant.

The purpose of the research was to develop such formulations of fodder protein-vitamin-mineral supplements that would complement the rations of repairing pigs and sows with the necessary nutritional elements in the corresponding physiological periods, their number and methods of use in 
order to ensure high animal productivity and economic efficiency of the industry.

Material and methods of research: the research was carried out during 2010-2015 at the Institute of Agriculture of the steppe regions of the NAAS of Ukraine by the method of VASGNIL [7]. In experiments used repair guinea pigs of large white breed, sows of two farms, received posterity.

The method of group-analogues (control and experimental), taking into account age, live weight and physiological state, carried out five scientific and economic experiments on pigs with two farrowing sows per year: 1 - feeding of repair guinea pigs with the use of improved targeted feeding additives, 2 feeding Pig sows with the use of developed feed additives and their effect on fetal development, 3 - feeding of pigs from the first farrower to 6 months of age with the use of improved feed additives, 4 - the impact of improved feed supplements on Sow productivity and growth of offspring from the second farrowing to 45 days; 5 - feeding of the pigs from the second farrowor to 6 months of age using targeted feeding additives.

The rations of animal feeding were composed of own production feeds, traditional for the steppe zone of Ukraine [11]. In all periods of the physiological state of sows, concentrated feed (barley, oats, wheat, corn, sunflower, wheat bran) - comprised 76.75 to $92.13 \%$, including high-protein 7.75-6.29\%; Alfalfa hay and silage of corn class 1 - 13,56-5,98\%, root crops 4,65 and fresh milk wheat $-5,04-1,89 \%$.

In all experiments, the main factor for studying was the effectiveness of the use of improved protein-vitamin-mineral supplements compared to standard ones in relation to the biogeochemical zone and the pig production group.

The feeding of pigs was organized in accordance with the recommendations of VASGNIL [6] under the same conditions of retention. In order to cover the deficiency found in the composition of compound feed, guinea pigs of the control group were given a protein-vitamin-mineral feed supplement 
according to the standard formulation [12], and the experimental one - a feed additive with an improved formulation.

Results of own research The determined actual chemical composition and nutrition of feeds served as the basis for the analysis of existing standard formulations of protein-vitamin and mineral feed additives and the need for a direction for their improvement [2]. It was found that in different age periods, the deficit of energy nutrition of rations is $26 \%$, protein - up to $9 \%$, including the digestive 13-16, lysine 13-17, methionine + cystine 5-10, macrocells - up to $45 \%$ in t Calcium $36-72$, phosphorus - $6-52$, microelements $-81 \%$, of which copper - 34, zinc - 23-46, cobalt - 83, vitamin D - 70-90, riboflavin - 4-12, nicotinic acid - 64, cyanocobalamin - 98\%. At the same time, an excess of crude fiber was found - from $13 \%$ to 2.7 times; Iron - from $45 \%$ to 1.5 times; Manganese - from $10 \%$ to 1.5 times.

Due to the fact that the feeds of the main rations did not meet the animal's need for the nutrient and biologically active substances, protein-vitamin and mineral feed additives were used in order to maximize their deficiency of nutritional elements [9].

Balancing of diets was carried out in the control group at the expense of the standard feed supplement - TU-8-3-62, recipe 52-4 according to the recommended feed technology - $18 \%$ per tonne of feed for growing period from 4 to 8 months of age [1]. The experimental group's pigs' diets were balanced with improved, monthly-adjusted recipes of protein-vitamin-mineral feed additives and introduced them into compound feeds, taking into account the growth of the pigs and the corresponding changes in their need for separate nutrition elements.

Improved supplements are designed for 6, 7, 8-month-old pigs and their introduction for 1 ton of mixed feed is not $18 \%$, and accordingly $8.3 ; 8.19$ and $6.3 \%$.

Methodical principle of optimization of the composition of protein-vitaminmineral feed additives was as follows: after the analysis of blood, fodder and rations revealed a shortage of individual nutrients, on the basis of which 
developed the appropriate formulation with the introduction of those (and in such quantity) of components, which and how many did not suffice. Diet [10].

Following the results of feeding the guinea pig with the use of improved feed additives in the first experiment, in assessing their effectiveness, the dynamics of live weight of animals from 5 to 8 months of age was monitored (table 1). The pigs of the experimental group at the expense of higher growth energy at 7 and 8 months achieved a higher live weight compared with the control animals.

1. Index of growth of experimental piggy-wiggies, $X \pm S x$

\begin{tabular}{|c|c|c|c|c|c|c|c|}
\hline \multirow[b]{3}{*}{ Group } & \multicolumn{7}{|c|}{ Eyelids of animals, months } \\
\hline & \multirow[b]{2}{*}{\begin{tabular}{|c|}
5 \\
living \\
mass a \\
1 goal \\
on \\
beginnin \\
g \\
experience \\
kg \\
\end{tabular}} & \multicolumn{2}{|c|}{6} & \multicolumn{2}{|c|}{7} & \multicolumn{2}{|c|}{8} \\
\hline & & $\begin{array}{l}\text { living } \\
\text { mass } 1 \\
\text { goal on } \\
\text { end } \\
\text { period, } \\
\text { kg }\end{array}$ & $\begin{array}{c}\text { middling } \\
\text { day's } \\
\text { increase, } \\
\text { r }\end{array}$ & $\begin{array}{l}\text { living } \\
\text { mass } 1 \\
\text { goal on } \\
\text { end } \\
\text { period, } \\
\text { kg }\end{array}$ & $\begin{array}{c}\text { middling } \\
\text { day's } \\
\text { increase, } \\
\text { г }\end{array}$ & $\begin{array}{l}\text { living } \\
\text { mass } 1 \\
\text { goal on } \\
\text { end } \\
\text { period, } \\
\text { kg }\end{array}$ & $\begin{array}{c}\text { middling } \\
\text { day's } \\
\text { increase, } \\
\Gamma\end{array}$ \\
\hline $\begin{array}{l}\text { Control, } \\
n=37\end{array}$ & $\begin{array}{c}53,0 \pm 0,6 \\
0\end{array}$ & $\begin{array}{c}71,7 \pm 0,9 \\
2 \\
\end{array}$ & $\begin{array}{l}623,0 \pm 7,6 \\
2\end{array}$ & $90,8 \pm 1,75$ & $636,0 \pm 6,94$ & $112,0 \pm 2,97$ & $707,0 \pm 8,36$ \\
\hline $\begin{array}{l}\text { Experimenta } \\
n=37\end{array}$ & $53,0 \pm 0,60$ & $\begin{array}{c}72,4 \pm 0,9 \\
7\end{array}$ & $\begin{array}{l}647,0 \pm 6,4 \\
8\end{array}$ & $94,3 \pm 1,83$ & $730,0 \pm 7,16$ & $124,0 \pm 2,65^{* * *}$ & $990,0 \pm 9,14^{* * *}$ \\
\hline
\end{tabular}

The effectiveness of using protein-vitamin-mineral supplements based on the improved recipes is also confirmed by the biochemical parameters of the blood serum of the experimental group of sows that conformed to the norm and indicated an optimal metabolism in their body. Indicators of animals in the control group from 84 to 104 days of fertility were reduced to the lower limit of the norm for the content of protein, alkaline reserves, calcium, phosphorus.

Positive influence of the use of improved protein-vitamin-mineral feed additives is also established in the study of the development of sows (Table 2.).

The natural, statistically significant $(P<0.05-P<0.001)$ increase in live weight and body length of the fruit occurred in the mothers of both 
experimental groups, but in the experimental group these indices were more pronounced.

2. Dynamics of development of garden-stuffs of sows, $X \pm S x$

\begin{tabular}{|c|c|c|c|c|c|}
\hline \multirow{2}{*}{$\begin{array}{c}\text { Age of } \\
\text { fruit, } \\
\text { days }\end{array}$} & \multirow[b]{2}{*}{ Index } & \multicolumn{2}{|c|}{ Group } & \multicolumn{2}{|c|}{$\begin{array}{c} \pm \text { experimental to the } \\
\text { control }\end{array}$} \\
\hline & & $\begin{array}{c}\text { control, } \\
n=6\end{array}$ & $\begin{array}{c}\text { experimental, } \\
n=6\end{array}$ & difference & $\%$ \\
\hline \multirow[t]{3}{*}{$39-40$} & $\begin{array}{l}\text { Amount of garden- } \\
\text { stuffs }\end{array}$ & $12,7 \pm 0,88$ & $13,3 \pm 0,33$ & $+0,6$ & 4,7 \\
\hline & Mass, $\Gamma$ & $28,15 \pm 0,48$ & $30,16 \pm 0,391^{*}$ & $+2,01$ & 7,14 \\
\hline & Length, мM & $45 \pm 0,6$ & $51 \pm 0,5^{*}$ & $+6,00$ & 13,33 \\
\hline \multirow[t]{3}{*}{ 84-90 } & $\begin{array}{l}\text { Amount of garden- } \\
\text { stuffs }\end{array}$ & $11,5 \pm 0,87$ & $12,0 \pm 0,58$ & $+0,5$ & 4,3 \\
\hline & Mass, $\Gamma$ & $762 \pm 4,6$ & $840 \pm 4,3^{*}$ & $+33,00$ & 10,24 \\
\hline & Length, мм & $196 \pm 0,4$ & $229 \pm 0,2^{* *}$ & $+33,00$ & 16,84 \\
\hline \multirow[t]{3}{*}{114} & $\begin{array}{l}\text { Amount of garden- } \\
\text { stuffs }\end{array}$ & $10,97 \pm 0,150$ & $11,06 \pm 0,262$ & $+0,09$ & 0,82 \\
\hline & Mass, $\Gamma$ & $1220 \pm 0,015$ & $1440 \pm 0,085^{* *}$ & $+0,220$ & 18,03 \\
\hline & Length, мм & $247 \pm 7,8$ & $298 \pm 8,6$ *** & $+51,00$ & 20,65 \\
\hline
\end{tabular}

Note: * $P<0,05,{ }^{* *} P<0,01,{ }^{* * *} P<0,001$

In the experimental group, stillbirth piglets were $5.6 \%$ less; Born with a weight below $1 \mathrm{~kg}-7.05 \%$; Born of a weight of $1 \mathrm{~kg}$ and above - more by $16.54 \%$; In each nest extra viable piglets were obtained per sow - 1.45 heads and the weight difference of the nest at birth in favor of the experimental person was $+37.19 \%$.

The advantage of development of piglets in 21 days and at 45 days of age and on the milk productivity of subsistence sows indicates an increased biological value and the productive effect of the experimental diet to provide the sows with a set of necessary nutritional elements.

Indicators of the influence of improved supplements through the mother on the intensity of growth and development of the obtained pigs from the first farrow indicate that the experimental group pigs throughout the growing season had a higher, statistically significant $(P<0.001)$ growth rate and live weight and lower feed unit expenditure And digestible protein by $1 \mathrm{~kg}$ increment. At the expense of an increase in average daily increments ( $P$ $<0.001$ ), the pigs of the experimental group already at the age of 6 months achieved a live weight at the level of 1 class $(114.03 \pm 1.975 \mathrm{~kg})$, which is 
more than that of the control group analogues even at 7 months $(111.57 \pm$ $1,138 \mathrm{~kg})$.

As a result of the increased conversion of the experimental group, the pigs of the experimental group spent $1 \mathrm{~kg}$ of growth on the growth of $18.79 \%$ and $12.47 \%$ less feed units and digestible protein than on the control group.

The results of the balance experiment testify to a higher production efficacy and the effectiveness of the use of improved feed additives. Permeability of the nutrients of feed was higher in the pigs of the experimental group: dry matter by $4.3 \%(P<0.01)$; Organic substances 3.4\% ( $P<0.05)$; Crude protein - 3.5\% ( $P<0.01)$; Crude fat $-4,5 \%(P<0,05)$; Bezazoznostichnyh extractive substances - 6,2\% ( $P<0,001)$; Crude fiber $5,8 \%(P<0,05)$.

The obtained results of improving the use of nitrogen agree with the increase in protein digestibility [5]. Compared with the control group in the experiment, the nitrogen consumed was postponed by $8.7 \%(P<0.05)$, and the digested dose by $12.3 \%$ more $(P<0.01)$, which was reflected in the growth of animals in the experiment: The group average daily gain was $19 \%$ higher than in the control group.

Indicators of digestibility of nutrients substantially complement and data on the daily use of minerals in test specimens [13]. Calcium was absorbed more in animals of the experimental group at $0.87 \mathrm{~g}(8.3 \%, P<0.01)$. The advantage of experimental group pigs in using phosphorus from food fed with control pigs was $0.72 \mathrm{~g}(9.4 \% ; \mathrm{P}<0.01)$.

The positive results of the growth of piglets up to 45 days and the piglets up to 6 months of age, obtained in the second farrow from the same sows, were also naturally obtained $(P<0.01-P<0.001)$, under the influence of improved protein-vitamin-mineral feed additives [ 8].

The obtained indicators of meat productivity of descendants are confirmed and in the future, high efficiency of the use of advanced supplements in comparison with standard (tab. 3.). 
3. Productivity of sows and growth of piglings, $X \pm S x$

\begin{tabular}{|l|c|c|}
\hline \multirow{2}{*}{\multicolumn{1}{|c|}{ Index }} & \multicolumn{2}{c|}{ Group } \\
\cline { 2 - 3 } & Control, $\mathrm{n}=46$ & $\begin{array}{c}\text { Experimental, } \\
\mathrm{n}=53\end{array}$ \\
\hline It was born all the piglings, heads & 501 & 620 \\
\hline Living mass of a 1 pigling at birth, $\mathrm{kg}$ & $1,37 \pm 0,027$ & $1,56 \pm 0,031^{* *}$ \\
\hline Mass of nest at birth, $\mathrm{kg}$ & $10,97 \pm 0,601$ & $15,05 \pm 0,750^{* *}$ \\
\hline Mass of nest in 45-daily age, $\mathrm{kg}$ & $136,06 \pm 0,259$ & $205,10 \pm 0,350^{* * *}$ \\
\hline Mass of a 1 pigling at the separation in 45 days, $\mathrm{kg}$ & $14,40 \pm 0,228$ & $18,28 \pm 0,364^{* * *}$ \\
\hline Average daily increase of a 1 pigling for 45 days, $\mathrm{r}$ & $290 \pm 5,8$ & $330 \pm 6,6^{* * *}$ \\
\hline Well-kept of piglings, \% & 100 & 100 \\
\hline Living mass of a 1 chairman in 6-monthly age, $\mathrm{kg}$ & $92,18 \pm 1,843$ & $116,16 \pm 2,323^{* * *}$ \\
\hline $\begin{array}{l}\text { Average daily increase of a 1 chairman for 6 } \\
\text { months, } \Gamma\end{array}$ & $505 \pm 6,7$ & $639 \pm 8,8^{* * *}$ \\
\hline
\end{tabular}

In addition to the positive dynamics of live weight, average daily increments, feed remuneration and other indicators, it is equally important to study the effects of improved balancing feed additives on the meat-and-fat productivity of experimental pigs.

In the pigs of the experimental group were $1.2 \%$ higher slaughter output, the length of the carcass $-3.4 \%(3.3 \mathrm{~cm})$. But there is no probable difference in the area of the "muscular cell" and the mass of the rear third of the cooled semitatus. The thickness of the pike at the 6-7 thoracic vertebra was $1.6 \mathrm{~mm}$, or $5.44 \%$ less than that of the control. The muscle tissue in them contained more dry matter, had a higher moisture capacity and less losses in heat treatment, which improves its culinary properties. According to the chemical composition of the longest back muscle, no significant difference was found between the groups.

By the content of fat in meat, the control animals were dominated by $1.65 \%$, but it was not so small in the experimental group as to worsen the taste and culinary properties of the meat - when tasting, all the samples received a high score (8-9 points) .

Long-term feeding of improved feed additives in the composition of feed for pigs in the experimental group not only did not negatively affect the slaughter, meat and fat, physico-chemical and organoleptic parameters of the products, and there was a positive trend towards their improvement. 
The introduction of improved protein-vitamin-mineral feed supplements into compound feed provided an increase in the cost-effectiveness of the cost per hryvnia from 11 to $53 \mathrm{UAH}$. Growing pigs using balancing additives, taking into account the biogeochemical province and the actual feeding of feed in the technological groups of animals, provided a high economic effect not only in the first, but also in the second farrow, which gives grounds to predict the subsequent effect in subsequent generations, as the research shows: than The longer the use of protein-vitamin-mineral supplements based on the improved recipes, the higher their effectiveness. The production testing and implementation of the development on 156 sows also confirmed the high economic efficiency of improved targeted feed additives.

\section{Bibliography}

1. Rational use of feed grains in the livestock production/N. F. Kulik, T. V. Drought A. V. Zhmud et al.//Effective feed and feeding. - 2007. - № 2 (18). - P. $11-14$.

2. Nesdale S. V. Innovative way of development of feed industry agroindustrial complex of Ukraine/Sec.In. Nesdoly//Efficient feed and feeding. - 2006. — № 1 (9). - S. 12 - 13.

3. Ovsyannikov A. S. Fundamentals of experimental work in animal husbandry/A. S. Ovsyannikov. - M.: Kolos, 1976. - P. 86 - 130.

4. Ryzhov S. New developments in the preparation of compound feeds and fodder mixes in farms/ Sec. Ryzhov//Feed. - 2000. - No. 7. - S. 15.

5. Norms and rations of feeding of agricultural animals: cases. manual/A. P. Kalashnikov, A. M. Pecina, V. A. Shcheglov, etc.; under the editorship of A. P. Kalashnikov, V. S. Fisinin, V. V. Shcheglov, N. S. Kleimenova. - [3rd ed.] - M., 2003. -456 p.

6. Svezhintsov A. I. normalized the feeding of pigs: proc. manual/A. I. Swienton, Th. Tailors, J. I. Pivtorak. — Lviv: LKT of LAWM, 2005. - 385 p. 
7. Mineral nutrition of animals/Charles T. Klanco, Bibliography M. F. Kulik, N. In. Kosenko, V. T. Lisovenko. - K.: World, 2001. - 576 p.

8. Polishchuk A. A. ways of effectively growing and fattening pigs/A. A. Polishchuk//farmers. — 2004. — № 1 - 2. - Pp. 29 - 30.

9. Ibatullin I. Feeding of farm animals/I. I. Ibatullin, D. A., Melnychuk, G. A. Bogdanov. - Vinnitsa: New book, 2007. - 616 p.

10. The dynamics of changes in chemical composition and nutritional value of the feed for the 20-year period.In Rudenko, S. S., Barchuk, S. A. Shapovalov, N. D. Wholesale//NTB, Institute of animal breeding UAAS. H., 2006. - No. 94. - S. $273-282$.

11. Nerubenko, A. V. Feed mixture of a new technology generation in growing gilts/A. V. Nerubenko, D. F. Ryndin, I. S. Have Moshkutelo// Husbandry. - 2009. - No. 10. - P. $25-26$.

12. Franic N.. The efficacy of protein-vitamin-mineral supplements in the diets of piglets and weaners/N.. Franuc//Husbandry. - 2006. - No. 2. P. $17-18$.

13. Podobed L. S. Optimization of feeding and keeping pigs early age/L. S. Podobed. - K., 2004. - 149 S. 